\title{
Analisis Pengaruh Faktor Non-Ekonomi terhadap Sikap Pedagang Madura dalam Membayar Zakat Perdagangan
}

\section{Analysis of The Effect of Non-Economics Factors on Madurese Traders Attitudes in Paying Zakah on Trade}

\author{
Nely Novia ${ }^{1}$, Iswan Noor ${ }^{2}$, Marlina Ekawaty ${ }^{3}$ \\ ${ }^{1}$ Universitas Brawijaya, Malang 65300, email: nelynovia8@gmail.com \\ ${ }^{2}$ Universitas Brawijaya, Malang 65300, email: iswannoor@yahoo.co.id \\ ${ }^{3}$ Universitas Brawijaya, Malang 65300, email: marlina_ekawaty@yahoo.com
}

\begin{abstract}
Zakah maal is one of the kind of zakat that must be paid by muslims who work as traders and have the treasures that reach nisab, haul, and also fulfill other conditions. The purpose of this research is to know the influence of non-economic factors namely knowledge of zakah on trade $\left(\mathrm{X}_{1}\right)$, work environment $\left(\mathrm{X}_{2}\right)$, religiosity $\left(\mathrm{X}_{3}\right)$, and education $\left(\mathrm{X}_{4}\right)$ on the attitudes of Madurese traders in Malang in paying zakah on trade $(\mathrm{Y})$. The method used in this study is multinomial logit analysis. The results of this study indicate that simultaneously the knowledge $\left(\mathrm{X}_{1}\right)$, work environment $\left(\mathrm{X}_{2}\right)$, religiosity $\left(\mathrm{X}_{3}\right)$, and education $\left(\mathrm{X}_{4}\right)$ significantly influence the attitude of Madurese traders in paying zakah on trade $(\mathrm{Y})$. Further partially, Madurese traders' attitude in paying zakah on trade (Y) is influenced by knowledge $\left(\mathrm{X}_{1}\right)$, work environment $\left(\mathrm{X}_{2}\right)$, religiosity $\left(\mathrm{X}_{3}\right)$, and education $\left(\mathrm{X}_{4}\right)$.
\end{abstract}

Keywords: education, knowledge, religiosity, work environment, zakah on trade

\begin{abstract}
Abstrak. Zakat maal merupakan salah satu jenis zakat yang wajib dibayarkan oleh umat muslim yang berprofesi sebagai pedagang yang hartanya telah mencapai nisab, haul, dan juga telah memenuhi syaratsyarat lainnya. Tujuan penelitian ini untuk mengetahui pengaruh faktor non-ekonomi, yaitu pengetahuan zakat perdagangan $\left(\mathrm{X}_{1}\right)$, lingkungan kerja $\left(\mathrm{X}_{2}\right)$, religiusitas $\left(\mathrm{X}_{3}\right)$, dan pendidikan $\left(\mathrm{X}_{4}\right)$ terhadap sikap pedagang Madura di Kota Malang dalam membayar zakat perdagangan (Y). Metode yang digunakan dalam penelitian ini menggunakan analisis multinomial logit. Hasil penelitian ini menunjukkan bahwa secara simultan, pengetahuan $\left(\mathrm{X}_{1}\right)$, lingkungan kerja $\left(\mathrm{X}_{2}\right)$, religiusitas $\left(\mathrm{X}_{3}\right)$, dan pendidikan $\left(\mathrm{X}_{4}\right)$ berpengaruh secara signifikan terhadap sikap pedagang Madura dalam membayar zakat perdagangan (Y). Selanjutnya secara parsial, sikap pedagang Madura dalam membayar zakat perdagangan ( $\mathrm{Y}$ ) dipengaruhi oleh pengetahuan $\left(\mathrm{X}_{1}\right)$ dan lingkungan kerja $\left(\mathrm{X}_{2}\right)$ secara signifikan. Religiusitas $\left(\mathrm{X}_{3}\right)$ dan pendidikan $\left(\mathrm{X}_{4}\right)$ secara parsial tidak berpengaruh secara signifikan terhadap sikap pedagang Madura dalam membayar zakat perdagangan $(\mathrm{Y})$.
\end{abstract}

Kata kunci: lingkungan kerja, pendidikan, pengetahuan, religiusitas, zakat perdagangan

\section{PENDAHULUAN}

Keadilan dalam perspektif Islam, yaitu tidak terjadi ketimpangan sosial dan pendapatan yang terdistribusi dengan merata. Salah satu cara untuk mencapai keadilan dalam berbagai aspek kehidupan manusia, Islam menganjurkan untuk membayar zakat. Dalam Al-Quran, Surat Maryam ayat 3 juga telah dijelaskan bahwa manusia diperintahkan untuk mendirikan shalat dan menunaikan zakat. zakat terbagi menjadi dua, yaitu zakat fitrah dan zakat maal. Untuk zakat maal sendiri banyak jenisnya dan salah satunya adalah zakat perdagangan. Manfaat pembayaran zakat perdagangan adalah menghindari dari sifat kikir dan serakah, menyucikan harta yang kotor, menumbuhkan dan mendidik kasih sayang dan rasa peduli terhadap golongan lemah, serta mendidik dan melatih untuk taat terhadap perintah Allah SWT.

Kota Malang merupakan salah satu kota besar yang mayoritas penduduknya beragama Islam. Di Kota Malang juga terdapat banyak masyarakat pendatang yang berasal dari berbagai daerah yang mayoritas bertujuan untuk mengadu nasib dan menempuh pendidikan. Salah satu masyarakat yang banyak melakukan urbanisasi ke Kota Malang adalah masyarakat Madura. Berdasarkan penelitian pendahuluan yang dilakukan oleh peneliti, dimana masyarakat Madura mayoritas berprofesi sebagai 
pedagang. Hal tersebut dikarenakan kurang memadainya keahlian yang dimiliki serta ajakan sanak saudara dan teman. Bahkan sebagian besar dari masyarakat Madura yang berada di Kota Malang mulai menetap dan sebagian juga tidak. Sehingga tidak salah jika Kota Malang dianggap sebagai salah satu kota besar yang memiliki daya tarik tersendiri bagi masyarakat Madura dikarenakan fasilitas sarana dan prasarana serta lapangan pekerjaan dianggap dapat memenuhi kebutuahan mereka.

Perekonomian Kota Malang sendiri berkembang cukup pesat khususnya di sektor perdagangan dibandingkan sektor yang lain. Hal ini dapat dilihat dari Tabel 1 berikut yang menyajikan informasi tentang distribusi persentase PDRB atas harga berlaku Kota Malang tahun 2016.

Tabel 1 Distribusi persentase PDRB atas harga berlaku Kota Malang tahun 2016

\begin{tabular}{clc}
\hline No. & \multicolumn{1}{c}{ Lapangan Usaha } & $\mathbf{2 0 1 6}$ \\
\hline 1. & Pertanian, Kehutanan, dan Perikanan & 0.26 \\
2. & Pertambangan dan Penggalian & 3.77 \\
3. & Industri Pengolahan & 28.92 \\
4. & Pengadaan Listrik dan Gas & 0.03 \\
5. & Pengadaan Air, Pengelolaan Sampah, Limbah dan Daur Ulang & 0.19 \\
6. & Konstruksi & 12.92 \\
7. & Perdagangan Besar dan Eceran, Reparasi Mobil dan Sepeda Motor & 29.55 \\
8. & Transportasi dan Pergudangan & 2.45 \\
9. & Penyediaan Akomodasi dan Makan Minum & 4.90 \\
10. & Informasi dan Komunikasi & 3.99 \\
11. & Jasa Keuangan dan Asuransi & 3.05 \\
12. & Real Estate & 1.41 \\
13. & Jasa Perusahaan & 0.78 \\
14. & Administrasi Pemerintahan, Pertahanan dan Jaminan Sosial & 1.48 \\
15. & Jasa Pendidikan & 8.13 \\
16. & Jasa Kesehatan dan Kegiatan Sosial & 2.50 \\
17. & Jasa Lainnya & 2.87 \\
\hline
\end{tabular}

Sumber: diolah peneliti dari BPS Kota Malang (2017)

Berdasarkan Tabel 1 didapati bahwa sektor perdagangan di Kota Malang memiliki peranan penting dan utama dalam perekonomian Kota Malang. Selain itu, juga dapat diindikasikan bahwa dengan tingginya nilai distribusi persentase PDRB atas harga berlaku Kota Malang tahun 2016 pada sektor perdagangan dibandingkan sektor lain juga berdampak pada tingginya potensi pembayaran pajak dan zakat perdagangan. Selanjutnya, mayoritas masyarakat Madura yang berprofesi sebagai pedagang di Kota Malang ini juga diindikasikan memberikan kontribusi pada pembayaran pajak serta zakat perdagangan. Dengan begitu, pengumpulan dana zakat perdagangan di Kota Malang meningkat. Namun fenomena yang terjadi seringkali mengalami hambatan dalam pemungutan zakat yang disebabkan oleh banyak faktor.

Othman et al. (2017) dalam penelitiannya menunjukkan bahwa pengetahuan memiliki hubungan positif dan signifikan terhadap niat membayar zakat penghasilan. Dilanjutkan Azman dan Bidin (2015) mengemukakan bahwa variabel kelompok acuan berpengaruh positif dan signifikan terhadap perilaku kepatuhan zakat tabungan. Kemudian dilanjutkan dengan Ridlwan dan Sukmana (2017) yang menunjukkan bahwa religiusitas berpengaruh signifikan terhadap motivasi membayar zakat di agensi regional amil zakat Jawa Timur. Selanjutnya Sobana et al. (2016) dalam penelitiannya mengemukakan bahwa tingkat pendidikan berpengaruh terhadap kepatuhan zakat maal.

Penelitian ini dilakukan dengan tujuan mengetahui pengaruh faktor non-ekonomi terhadap sikap pedagang Madura dalam membayar zakat perdagangan. Adapun hipotesis dalam penelitian ini, yaitu terdapat pengaruh pengetahuan zakat perdagangan $\left(X_{1}\right)$, lingkungan kerja $\left(X_{2}\right)$, religiusitas $\left(X_{3}\right)$, dan pendidikan $\left(\mathrm{X}_{4}\right)$ terhadap sikap pedagang Madura dalam membayar zakat perdagangan $(\mathrm{Y})$. 


\section{TINJAUAN PUSTAKA}

Zakat perdagangan merupakan salah satu kewajiban bagi umat muslim yang berprofesi sebagai pedagang. Wajib zakat yang dikenakan pada individu yang berprofesi sebagai pedagang ini tentunya harus memenuhi syarat kekayaan dagang wajib zakat di antaranya niat berdagang, harta yang diperoleh dari berdagang mencapai haul (satu tahun), nisab (setara 85 gram emas), besarnya kadar zakat $2.5 \%$ dari pendapatan bersih, dalam pembayarannya dapat berupa barang atau uang (Hasbi, 2008).

Sikap merupakan suatu perilaku yang ditunjukkan seseorang dalam menanggapi peristiwa yang terjadi pada lingkungan di sekitarnya (Azwar, 2013). Menurut teori perilaku terencana, perilaku individu dipengaruhi oleh sikap, norma subjektif, dan kontrol perilaku. Sikap seseorang ini tentunya dipengaruhi oleh keyakinan mengenai perilaku yang dilakukan dan bersifat normatif. Sehingga sebelum melakukan suatu sikap tentunya seseorang meyakinkan dirinya terlebih dahulu apakah sikap yang dilakukan memberikan hasil seperti yang diinginkan dan sebaliknya. Selain itu, seorang individu dalam bersikap tentunya mengacu pada norma yang berlaku di lingkungan sekitarnya agar seorang individu dapat diterima dan untuk menghindari penolakan dari lingkungan sekitarnya. Kontrol perilaku sebelumnya juga memengaruhi individu, sehingga seorang individu akan mempertimbangkan kemudahan atau kesulitan dari sikap yang akan ditunjukkan. Sikap membayar zakat perdagangan tentunya dipengaruhi oleh banyak faktor yang dapat membuat seseorang cenderung membayar atau tidak membayar zakat perdagangan. Faktor tersebut dapat juga berupa faktor nonekonomi. Penelitian sebelumnya telah membuktikan bahwa terdapat faktor yang memengaruhi pembayaran zakat.

Keyakinan yang merupakan hasil dari pengamatan secara langsung dan melalui pembelajaran (pengetahuan) yang telah diperoleh tentunya dapat memengaruhi pembentukan sikap (Daud et al., 2011). Sukri et al. (2016) melakukan riset yang menunjukkan bahwa pengetahuan zakat berpengaruh signifikan terhadap kepatuhan membayar zakat emas pada staf UUM. Kemudian dilanjutkan dengan penelitian Othman et al. (2017) yang menunjukkan bahwa pengetahuan memiliki hubungan positif dan signifikan terhadap niat membayar zakat penghasilan. Selanjutnya Zakariah et al. (2018) dalam penelitiannya mengemukakan bahwa pengetahuan Islam berpengaruh terhadap motivasi muzaki dalam membayar zakat.

Perilaku seseorang dipengaruhi oleh orang-orang sekitar yang dijadikan sebagai acuan dalam berperilaku seperti teman, sahabat, dan keluarga (Azwar, 2013). Bakar dan Rashid (2010) dalam penelitiannya menunjukkan bahwa akademisi yang membayar zakat dipengaruhi oleh faktor sosial. Dilanjutkan dengan Ahmad et al. (2011) yang menunjukkan bahwa kelompok acuan (teman, relasi, dan kolega) berpengaruh positif dan signifikan terhadap kepatuhan membayar zakat

Heikal et al. (2014) melakukan penelitian tentang The Intention to Pay Zakat Commercial: An Application of Revised Theory of Planned Behavior menunjukkan bahwa norma subyektif berpengaruh positif dan signifikan terhadap niat muzaki untuk membayar zakat perdagangan di antara pedagang di Kota Lhokseumawe. Dilanjutkan Azman dan Bidin (2015) yang mengemukakan bahwa variabel kelompok acuan berpengaruh positif dan signifikan terhadap perilaku kepatuhan zakat tabungan. Selanjutnya Bin-Nashwan et al. (2017) melakukan riset tentang Perception of Business Owner toward Business Zakah Compliance Intention, menunjukkan bahwa norma subyektif berpengaruh signifikan terhadap niat kepatuhan zakat bisnis. Sedangkan penelitian oleh Ridlwan dan Sukmana (2017) menunjukkan faktor sosial tidak berpengaruh terhadap motivasi membayar zakat di BAZ wilayah Jawa Timur.

Religiusitas, Ahmad et al. (2011) meneliti tentang Tax-Based Modelling of Zakat Compliance, menunjukkan bahwa keimanan tidak berpengaruh signifikan terhadap kepatuhan zakat. Kemudian dilanjutkan dengan Sukri et al. (2016) yang menunjukkan bahwa nilai religiusitas tidak berpengaruh terhadap kepatuhan membayar zakat emas. Dilanjutkan Bakar dan Rashid (2010) dalam penelitiannya 
menunjukkan bahwa keimanan berpengaruh sangat signifikan terhadap kesadaran membayar zakat pendapatan. Idris et al. (2012) melakukan riset yang menunjukkan bahwa adanya hubungan positif dan signifikan antara religiusitas dan perilaku kepatuhan zakat bahkan religiusitas memiliki peranan penting dalam perilaku kepatuhan zakat.

Rosyadi (2013) melakukan riset tentang Model Prediksi Kepatuhan Menunaikan Zakat Maal, menunjukkan bahwa komitmen pada ajaran Islam berpengaruh positif terhadap kepatuhan menunaikan zakat maal. Berikutnya Mukhlis dan Beik (2013) melakukan riset yang menunjukkan bahwa faktor-faktor yang memengaruhi tingkat kepatuhan membayar zakat di Kabupaten Bogor adalah faktor keagamaan, seperti iman, pemahaman agama, dan balasan, lalu ada juga faktor-faktor lainnya seperti kepedulian sosial, kepuasan diri, dan organisasi.

Azman dan Bidin (2015) mengemukakan bahwa variabel religiusitas berpengaruh terhadap perilaku kepatuhan zakat tabungan. Sobana et al. (2016) mengemukakan komitmen pada aturan Islam berpengaruh terhadap kepatuhan zakat maal. Dilanjutkan dengan Perbawa dan Abdullah (2016) dalam penelitiannya menunjukkan bahwa religiusitas berpengaruh signifikan terhadap kesadaran membayar zakat di BAZNAS Indonesia.

Othman et al. (2017) dalam penelitiannya menunjukkan bahwa religiusitas berpengaruh positif dan signifikan terhadap niat membayar zakat pendapatan. Ridlwan dan Sukmana (2017) juga menunjukkan bahwa religiusitas berpengaruh signifikan terhadap motivasi membayar zakat di agensi regional amil zakat Jawa Timur.

Pada penelitian Merlinda (2015), pendidikan formal dan pendidikan informal tidak berpengaruh terhadap keputusan muslim dalam membayar zakat. Hal yang berbeda ditunjukkan oleh Ahmad et al. (2011) dimana pendidikan berpengaruh positif terhadap kepatuhan zakat. Selanjutnya Sobana et al. (2016) dalam penelitiannya mengemukakan bahwa tingkat pendidikan berpengaruh terhadap kepatuhan zakat maal.

\section{METODE}

Jenis data yang digunakan dalam penelitian ini adalah data primer. Data primer dalam penelitian diperoleh dari penyebaran kuesioner kepada pedagang Madura yang berada di pasar. Lokasi penelitian ini dilakukan di tiga pasar di Kota Malang, yaitu Pasar Gadang, Pasar Besar, dan Pasar Blimbing dengan pertimbangan bahwa ketiga pasar tersebut banyak terdapat orang Madura yang berprofesi sebagai pedagang.

Dalam mengumpulkan data pada penelitian ini peneliti menggunakan instrumen kuesioner. Jenis kuesioner yang digunakan dalam penelitian ini menggunakan jenis kuesioner tertutup. Kuesioner tertutup yang digunakan dalam penelitian ini menggunakan skala LIKERT dengan empat titik respon (sangat tidak setuju $(\mathrm{STS})=1$; tidak setuju $(\mathrm{TS})=2$; setuju $(\mathrm{S})=3$; dan sangat setuju $(\mathrm{SS})=4)$. Hal ini bertujuan untuk menghindari bias sosial yang disebabkan oleh kecenderungan responden untuk memilih netral apabila menggunakan jumlah titik respon sebanyak lima (Budiaji, 2013).

Populasi dalam penelitian ini adalah orang Madura yang melakukan urbanisasi ke Kota Malang dan berprofesi sebagai pedagang. Pengambilan sampel dilakukan dengan menggunakan teknik non probability sampling dengan teknik sampling accidental. Untuk jumlah sampel yang dipakai dalam penelitian ini, peneliti mengacu pada pendapat Roscoe (dalam Sugiyono, 2014) yang menyatakan bahwa jumlah sampel yang layak dalam sebuah penelitian antara 30 hingga 500 orang responden, sehingga peneliti menggunakan 100 orang responden dalam penelitian ini. 


\section{Uji Validitas dan Uji Reliabilitas}

Uji validitas dan uji reliabilitas dalam penelitian ini bertujuan untuk melihat apakah instrumen yang digunakan untuk pengumpulan data yang berupa kuesioner dengan skala LIKERT atau ordinal valid dan reliabel. Suatu kuesioner dikatakan valid apabila nilai koefisien $r_{\text {hitung }}$ yang hasilkan lebih besar dari nilai koefisien $r_{\text {tabel }}$ atau nilai signifikansi lebih kecil dari nilai $\alpha$ yang digunakan. Suatu kuesioner dikatakan reliabel apabila nilai koefisien Cronbach's Alpha lebih besar dari 0.60 (Sugiyono, 2014).

Variabel bebas dalam penelitian ini yang menggunakan uji validitas dan reliabilitas adalah variabel pengetahuan $\left(\mathrm{X}_{1}\right)$, lingkungan kerja $\left(\mathrm{X}_{2}\right)$, dan religiusitas $\left(\mathrm{X}_{3}\right)$ dikarenakan variabel tersebut menggunakan skala ordinal. Variabel pendidikan $\left(\mathrm{X}_{4}\right)$ dalam peneletian ini merupakan variabel berskala rasio. Berikut kerangka pemikiran yang digunakan dalam penelitian ini:

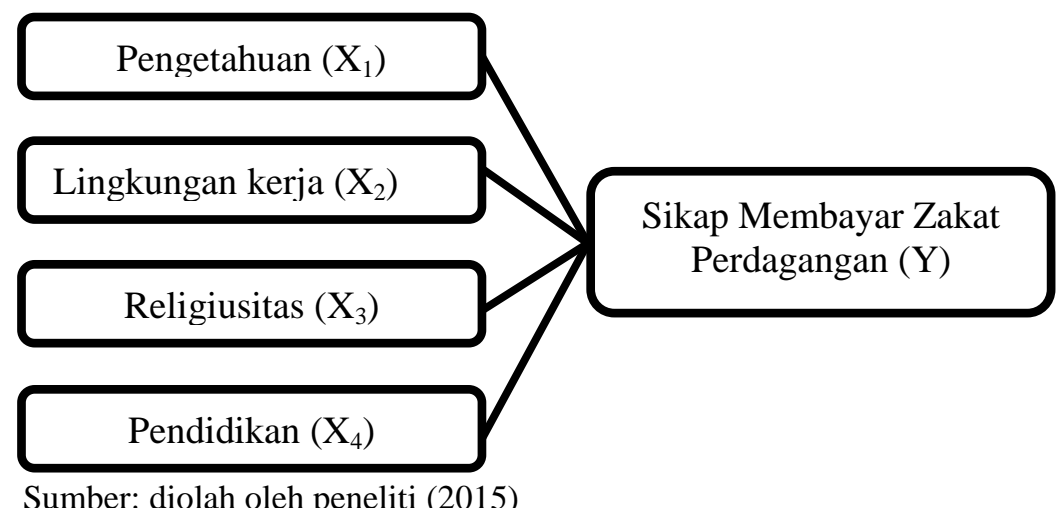

Gambar 1 Kerangka pemikiran

\section{Uji Multinomial Logit}

Multinomial logit (Nachrowi, 2008) merupakan model regresi dengan variabel bebas memiliki model respon lebih dari dua kelas. Untuk variabel pengetahuan $\left(\mathrm{X}_{1}\right)$, lingkungan kerja $\left(\mathrm{X}_{2}\right)$, dan religiusitas $\left(\mathrm{X}_{3}\right)$ merupakan variabel yang menggunakan skala ordinal, maka sebelum dilakukan uji multinomial logit, ketiga variabel tersebut perlu dikonversi dalam bentuk MSI (Ghozali, 2011; Sugiyono, 2014). Untuk variabel pendidikan $\left(\mathrm{X}_{4}\right)$ merupakan variabel rasio, yaitu berupa data tentang berapa lama pendidikan formal maupun non-formal yang ditempuh pedagang Madura. Berikut model ekonometrika dari faktor non-ekonomi yang memengaruhi sikap pedagang Madura dalam membayar zakat perdagangan yang digunkan dalam penelitian ini:

Persamaan Multinomial logit 1:

$$
\mathrm{L}_{\mathrm{n}}\left(\mathrm{p}_{2} / \mathrm{p}_{1}\right)=\beta_{21}+\beta_{21} \mathrm{PZPDG}+\beta_{22} \mathrm{LKRJ}+\beta_{23} \mathrm{RLGT}+\beta_{24} \mathrm{PND}
$$

Persamaan Multinomial logit 2:

$$
\mathrm{L}_{\mathrm{n}}\left(\mathrm{p}_{3} / \mathrm{p}_{1}\right)=\beta_{31}+\beta_{31} \mathrm{PZPDG}+\beta_{32} \mathrm{LKRJ}+\beta_{33} \mathrm{RLGT}+\beta_{34} \mathrm{PND}
$$

Keterangan:

$\mathrm{Y}_{\mathrm{i}}=$ Variabel terikat, yaitu sikap masyarakat Madura terhadap kewajiban membayar zakat perdagangan yang dibagi dalam tiga kategori:

1. tidak pernah membayar zakat perdagangan $\left(\mathrm{Y}=1\right.$ atau $\left.\mathrm{p}_{1}\right)$

2. kadang-kadang membayar zakat perdagangan $\left(\mathrm{Y}=2\right.$ atau $\left.\mathrm{p}_{2}\right)$

3. rutin membayar zakat perdagangan $\left(\mathrm{Y}=3\right.$ atau $\left.\mathrm{p}_{3}\right)$

$\beta=$ Konstanta

$\mathrm{X}_{1}=$ Pengetahuan zakat perdagangan (PZPDG)

$\mathrm{X}_{2}=$ Lingkungan kerja (LKRJ)

$\mathrm{X}_{3}=$ Religiusitas (RLGT)

$\mathrm{X}_{4}=$ Pendidikan (PND) 


\section{Hipotesis}

a. Semakin tinggi pengetahuan zakat perdagangan $\left(X_{1}\right)$, semakin rutin membayar zakat perdagangan.

b. Semakin tinggi pengaruh lingkungan kerja $\left(\mathrm{X}_{2}\right)$, semakin rutin membayar zakat perdagangan.

c. Semakin tinggi religiusitas $\left(\mathrm{X}_{3}\right)$, semakin rutin membayar zakat perdagangan.

d. Semakin lama menempuh pendidikan $\left(\mathrm{X}_{4}\right)$, semakin rutin membayar zakat perdagangan.

\section{HASIL DAN PEMBAHASAN}

\section{Validitas dan Reliabilitas}

Berikut Tabel 2 yang menyajikan hasil uji validitas instrumen penelitian dengan menggunakan SPSS.

Tabel 2 Uji validitas

\begin{tabular}{|c|c|c|c|c|c|}
\hline Variabel & Indikator & $\mathbf{r}_{\text {hitung }}$ & $\mathbf{r}_{\text {tabel }}$ & Sig. & Keterangan \\
\hline \multirow{6}{*}{$\begin{array}{c}\text { Pengetahuan } \\
\left(\mathrm{X}_{1}\right)\end{array}$} & $\mathrm{X}_{1.1}$ & $0.694^{* *}$ & 0.197 & 0.000 & VALID \\
\hline & $\mathrm{X}_{1} .2$ & $0.724^{* *}$ & 0.197 & 0.000 & VALID \\
\hline & $\mathrm{X}_{1} .3$ & $0.819^{* *}$ & 0.197 & 0.000 & VALID \\
\hline & $X_{1} .4$ & $0.835^{* *}$ & 0.197 & 0.000 & VALID \\
\hline & $X_{1} .5$ & $0.642^{* *}$ & 0.197 & 0.000 & VALID \\
\hline & $X_{1} .6$ & $0.816^{* *}$ & 0.197 & 0.000 & VALID \\
\hline \multirow{6}{*}{$\begin{array}{l}\text { Lingkungan } \\
\text { Kerja }\left(X_{2}\right)\end{array}$} & $\mathrm{X}_{3.1}$ & 0.146 & 0.197 & 0.148 & TIDAK VALID \\
\hline & $X_{3} .2$ & $0.811^{*}$ & 0.197 & 0.000 & VALID \\
\hline & $\mathrm{X}_{3} .3$ & 0.081 & 0.197 & 0.423 & TIDAK VALID \\
\hline & $X_{3} \cdot 4$ & 0.011 & 0.197 & 0.916 & TIDAK VALID \\
\hline & $X_{3} .5$ & $0.850^{* *}$ & 0.197 & 0.000 & VALID \\
\hline & $X_{3} .6$ & $0.555^{* *}$ & 0.197 & 0.000 & VALID \\
\hline \multirow{9}{*}{$\begin{array}{l}\text { Religiusitas } \\
\qquad\left(\mathrm{X}_{3}\right)\end{array}$} & $\mathrm{X}_{4.1}$ & 0.068 & 0.197 & 0.499 & TIDAK VALID \\
\hline & $\mathrm{X}_{4} \cdot 2$ & $0.723^{* *}$ & 0.197 & 0.000 & VALID \\
\hline & $\mathrm{X}_{4} \cdot 3$ & 0.125 & 0.197 & 0.216 & TIDAK VALID \\
\hline & $X_{4.4}$ & $0.706^{* *}$ & 0.197 & 0.000 & VALID \\
\hline & $X_{4} .5$ & $0.568^{* *}$ & 0.197 & 0.000 & VALID \\
\hline & $X_{4} .6$ & $0.574^{* *}$ & 0.197 & 0.000 & VALID \\
\hline & $X_{4} .7$ & $0.518^{* *}$ & 0.197 & 0.000 & VALID \\
\hline & $\mathrm{X}_{4.8}$ & $0.661^{* *}$ & 0.197 & 0.000 & VALID \\
\hline & $\mathrm{X}_{4.9}$ & $0.602^{* *}$ & 0.197 & 0.000 & VALID \\
\hline
\end{tabular}

Instrumen penelitian ini valid apabila nilai $r_{\text {hitung }}$ yang dihasilkan lebih besar dari $r_{\text {tabel }}$ atau nilai signifikansi lebih kecil dari nilai $\alpha=0.05(0.000<0.05)$. Hasil uji pada Tabel 2 menunjukkan bahwa semua indikator variabel pengetahuan $\left(\mathrm{X}_{1}\right)$ adalah valid, karena nilai $\mathrm{r}_{\text {hitung }}$ yang dihasilkan lebih besar dari $\mathrm{r}_{\text {tabel }}$ atau nilai signifikansi lebih kecil dari nilai $\alpha=0.05(0.000<0.05)$.

Untuk variabel lingkungan kerja $\left(\mathrm{X}_{3}\right)$ dan religiusitas $\left(\mathrm{X}_{4}\right)$ terdapat indikator yang tidak valid. Pada indikator variabel lingkungan kerja $\left(\mathrm{X}_{3}\right)$ nilai $\mathrm{r}_{\text {hitung }} \mathrm{X}_{3} .1$ sebesar $0.146, \mathrm{X}_{3} .3$ sebesar 0.081 , dan $\mathrm{X}_{3} .4$ sebesar 0.011 yang lebih kecil dari $r_{\text {tabel }}$ sebesar 0.197 atau nilai signifikansi pada indikator variabel lingkungan kerja $\mathrm{X}_{3} .1$ sebesar $0.148, \mathrm{X}_{3} .3$ sebesar 0.423 , dan $\mathrm{X}_{3} .4$ sebesar 0.916 yang lebih besar dari nilai $\alpha=0.05$. Maka indikator variabel lingkungan kerja $\mathrm{X}_{3} .1, \mathrm{X}_{3} .3$, dan $\mathrm{X}_{3} .4$ tidak valid dan dikeluarkan dari variabel $\mathrm{X}_{3}$.

Kemudian nilai $r_{\text {hitung }}$ pada indikator variabel religiusitas $\mathrm{X}_{4} .1$ sebesar 0.068 dan $\mathrm{X}_{4} .3$ sebesar 0.125 dimana lebih kecil dari $r_{\text {tabel }}$ sebesar 0.197 atau nilai signifikansi pada indikator variabel religiusitas $\mathrm{X}_{4} .1$ sebesar 0.499 dan $\mathrm{X}_{4.3}$ sebesar 0.216 dimana lebih besar dari nilai $\alpha=0,05$. Maka indikator variabel religiusitas $\mathrm{X}_{4.1}$ dan $\mathrm{X}_{4.3}$ tidak valid dan dikeluarkan dari variabel $\mathrm{X}_{4}$. Sehingga untuk 
analisis selanjutnya indikator variabel lingkungan kerja $\mathrm{X}_{3} .1, \mathrm{X}_{3} .3, \mathrm{X}_{3} \cdot 4$ dan religiusitas $\mathrm{X}_{4} .1, \mathrm{X}_{4} \cdot 3$ tidak digunakan.

\section{Reliabilitas}

Berikut Tabel 3 yang menyajikan hasil uji reliabilitas instrumen penelitian dengan menggunakan SPSS.

Tabel 3 Hasil uji reliabilitas instrumen penelitian

\begin{tabular}{lccc}
\hline \multicolumn{1}{c}{ Variabel } & Cronbach's Alpha & Koefisien Reliabilitas & Keterangan \\
\hline Pengetahuan $\left(\mathrm{X}_{1}\right)$ & 0.850 & 0.60 & Reliabel \\
Lingkungan Kerja $\left(\mathrm{X}_{3}\right)$ & 0.611 & 0.60 & Reliabel \\
Religiusitas $\left(\mathrm{X}_{4}\right)$ & 0.744 & 0.60 & Reliabel \\
\hline
\end{tabular}

Berdasarkan Tabel 3 hasil uji reliabilitas instrumen penelitian dapat dilihat bahwa nilai Cronbach's Alpha variabel pengetahuan $\left(\mathrm{X}_{1}\right)$, lingkungan kerja $\left(\mathrm{X}_{3}\right)$, dan religiusitas $\left(\mathrm{X}_{4}\right)$ lebih besar dari 0.60, artinya seluruh variabel tersebut adalah reliabel.

\section{Hasil Estimasi}

Hasil estimasi multinomial logit untuk sikap responden dalam membayar zakat perdagangan ditunjukkan pada Tabel 4 berikut.

Tabel 4 Parameter estimasi

\begin{tabular}{|c|c|c|c|c|c|c|c|c|c|}
\hline \multirow[b]{2}{*}{$\mathbf{Y}^{\mathbf{a}}$} & & \multirow[b]{2}{*}{ B } & \multirow[b]{2}{*}{$\begin{array}{l}\text { Std. } \\
\text { Error }\end{array}$} & \multirow[b]{2}{*}{ Wald } & \multirow[b]{2}{*}{ df } & \multirow[b]{2}{*}{ Sig. } & \multirow[b]{2}{*}{$\operatorname{Exp}(B)$} & \multicolumn{2}{|c|}{$\begin{array}{l}\text { 95\% Confidence } \\
\text { Interval for } \operatorname{Exp}(B)\end{array}$} \\
\hline & & & & & & & & $\begin{array}{l}\text { Lower } \\
\text { Bound }\end{array}$ & $\begin{array}{l}\text { Upper } \\
\text { Bound }\end{array}$ \\
\hline \multirow{5}{*}{$\begin{array}{l}\text { Kadang- } \\
\text { kadang } \\
\text { membayar } \\
\text { zakat } \\
\text { perdagangan }\end{array}$} & Intercept & -6.770 & 3.096 & 4.782 & 1 & .029 & & & \\
\hline & X1_PZPDG & .360 & .133 & 7.356 & 1 & $.007 *$ & 1.433 & 1.105 & 1.858 \\
\hline & X2_LKRJ & -.225 & .194 & 1.338 & 1 & .247 & .799 & .545 & 1.169 \\
\hline & X3_RLGT & .052 & .092 & .318 & 1 & .573 & 1.053 & .880 & 1.260 \\
\hline & X4_PND & .012 & .111 & .012 & 1 & .914 & 1.012 & .815 & 1.257 \\
\hline \multirow{5}{*}{$\begin{array}{l}\text { Rutin } \\
\text { membayar } \\
\text { zakat } \\
\text { perdagangan }\end{array}$} & Intercept & -8.425 & 2.888 & 8.509 & 1 & .004 & & & \\
\hline & X1_PZPDG & .520 & .130 & 16.064 & 1 & $.000^{*}$ & 1.683 & 1.305 & 2.170 \\
\hline & $\begin{array}{l}\text { X2_LKRJ } \\
\end{array}$ & -.499 & .183 & 7.415 & 1 & $.006^{*}$ & .607 & .424 & .870 \\
\hline & X3_RLGT & .011 & .085 & .016 & 1 & .900 & 1.011 & .855 & 1.195 \\
\hline & X4_PND & .138 & .099 & 1.942 & 1 & .163 & 1.148 & .946 & 1.393 \\
\hline
\end{tabular}

a. The reference category is: Tidak pernah membayar zakat perdagangan.
Keterangan : Koefisien determinasi Cox and Snell $=0.464$
Likelihood Ratio Tests Chi-Square $=62.302$
Nagelkerke $=0.534$
*) signifikan pada taraf 5\%
Sig. $=0.000$

Berikut interpretasi Tabel 4 mengenai koefisien-koefisien dalam model regresi logit multinomial dengan melihat nilai $\operatorname{Exp}(\mathrm{B})$ :

1 Persamaan multinomial logit 1 (Perbandingan antara Kategori Kadang-kadang Membayar Zakat Perdagangan $[\mathrm{Y}=2]$ dengan Tidak Pernah Membayar Zakat Perdagangan [Y = 1])

$$
\mathrm{L}_{\mathrm{n}}\left(\mathrm{p}_{2} / \mathrm{p}_{1}\right)=-6.770+0.360 \mathrm{PZPDG}-0.225 \mathrm{LKRJ}+0.052 \mathrm{RLGT}+0.012 \mathrm{PND}
$$


Apabila persamaan multinomial logit 1 dimasukkan nilai 0, yang berarti: pedagang Madura yang memiliki pengetahuan zakat perdagangan, dipengaruhi lingkungan kerja, memiliki religiusitas, motivasi ekonomi, dan pendidikan, maka akan didapati persamaan:

$$
\begin{aligned}
& \operatorname{Ln}\left(\mathrm{p}_{2} / \mathrm{p}_{1}\right)=-6.770 \\
& \left(\mathrm{p}_{2} / \mathrm{p}_{1}\right)=\operatorname{Exp}(-6.770)=0.00115 \\
& \mathrm{p}_{2}=0.00115 \mathrm{p}_{1}
\end{aligned}
$$

Berdasarkan persamaan tersebut dapat diartikan bahwa peluang pedagang Madura yang memiliki pengetahuan zakat perdagangan, pendapatan, dipengaruhi lingkungan kerja, memiliki religiusitas, motivasi ekonomi, dan pendidikan untuk bersikap kadang-kadang membayar zakat perdagangan 0.00115 kali peluang dibandingkan bersikap tidak pernah membayar zakat perdagangan. Untuk model persamaan multinomial logit 1 secara lebih rinci, yaitu dengan melihat nilai koefisien B pada masingmasing faktor yang terdiri dari:

Nilai koefisien pengetahuan zakat perdagangan (X_PZP) sebesar 0.360 dan Exp (B) sebesar 1.433 yang berarti, pedagang Madura yang memiliki pengetahuan zakat perdagangan yang tinggi mempunyai peluang yang lebih besar dibandingkan pedagang Madura yang memiliki pengetahuan zakat perdagangan rendah untuk bersikap kadang-kadang membayar zakat perdagangan dibandingkan tidak pernah membayar zakat perdagangan, dimana besarnya peluang pedagang Madura yang memiliki pengetahuan zakat perdagangan tinggi untuk kadang-kadang membayar zakat perdagangan sebesar 1.433 kali dibandingkan tidak pernah membayar zakat perdagangan.

Nilai koefisien lingkungan kerja $\left(\mathrm{X}_{2}\right.$ LKRJ) sebesar -0.255 dan Exp (B) sebesar 0.799. Nilai koefisien lingkungan kerja bertanda negatif berarti tingginya pengaruh lingkungan kerja pedagang Madura mempunyai peluang yang lebih kecil dibandingkan rendahnya pengaruh lingkungan kerja pedagang Madura untuk bersikap kadang-kadang membayar zakat perdagangan dibandingkan tidak pernah membayar zakat perdagangan, dimana peluangnya sebesar 0.799 kali. Berarti tingginya pengaruh lingkungan kerja pedagang Madura lebih berpeluang untuk tidak pernah membayar zakat perdagangan dibandingkan kadang-kadang membayar zakat perdagangan.

Nilai koefisien religiusitas ( $\mathrm{X}_{3}$ RLGT) sebesar 0.052 dan Exp (B) sebesar 1.053 yang berarti, pedagang Madura yang memiliki religiusitas tinggi mempunyai peluang yang lebih besar dibandingkan pedagang Madura yang memiliki religiusitas rendah untuk bersikap kadang-kadang membayar zakat perdagangan dibandingkan tidak pernah membayar zakat perdagangan, dimana besarnya peluang pedagang Madura yang memiliki religiusitas tinggi untuk kadang-kadang membayar zakat perdagangan sebesar 1.053 kali dibandingkan tidak pernah membayar zakat perdagangan.

Nilai koefisien pendidikan (X_PND) sebesar 0.012 dan Exp (B) sebesar 1.012 yang berarti, pedagang Madura yang menempuh pendidikan lebih lama mempunyai peluang yang lebih besar dibandingkan pedagang Madura yang hanya sebentar menempuh pendidikan untuk bersikap kadang-kadang membayar zakat perdagangan dibandingkan tidak pernah membayar zakat perdagangan, dimana besarnya peluang pedagang Madura yang menempuh pendidikan lebih lama untuk kadang-kadang membayar zakat perdagangan sebesar 1.012 kali dibandingkan tidak pernah membayar zakat perdagangan.

2 Persamaan multinomial logit 2 (Perbandingan antara Kategori Rutin Membayar Zakat Perdagangan [Y $=3$ ] dengan Tidak Pernah Membayar Zakat Perdagangan [Y=1])

$$
\mathrm{L}_{\mathrm{n}}\left(\mathrm{p}_{3} / \mathrm{p}_{1}\right)=-8.425+0.520 \mathrm{PZPDG}-0.499 \mathrm{LKRJ}+0.011 \mathrm{RLGT}+0.138 \mathrm{PND}
$$


Apabila persamaan multinomial logit 2 dimasukkan nilai 0, yang berarti : pedagang Madura yang memiliki pengetahuan zakat perdagangan, dipengaruhi lingkungan kerja, memiliki religiusitas, motivasi ekonomi, dan pendidikan, maka akan didapati persamaan:

$$
\begin{aligned}
& \operatorname{Ln}\left(\mathrm{p}_{2} / \mathrm{p}_{1}\right)=-8.425 \\
& \left(\mathrm{p}_{2} / \mathrm{p}_{1}\right)=\operatorname{Exp}(-8.425)=0.000219 \\
& \mathrm{p}_{2}=0.000219 \mathrm{p}_{1}
\end{aligned}
$$

Berdasarkan persamaan tersebut dapat diartikan bahwa peluang pedagang Madura yang memiliki pengetahuan zakat perdagangan, pendapatan, dipengaruhi lingkungan kerja, memiliki religiusitas, motivasi ekonomi, dan pendidikan untuk bersikap rutin membayar zakat perdagangan 0.000219 kali peluang dibandingkan bersikap tidak pernah membayar zakat perdagangan. Untuk model persamaan multinomial logit 2 secara lebih rinci, yaitu dengan melihat nilai koefisien B pada masing-masing faktor yang terdiri dari:

Nilai koefisien pengetahuan zakat perdagangan $\left(\mathrm{X}_{1-} \mathrm{PZP}\right)$ sebesar 0.520 dan Exp (B) sebesar 1.683 yang berarti, pedagang Madura yang memiliki pengetahuan zakat perdagangan yang tinggi mempunyai peluang yang lebih besar dibandingkan pedagang Madura yang memiliki pengetahuan zakat perdagangan rendah untuk bersikap rutin membayar zakat perdagangan dibandingkan tidak pernah membayar zakat perdagangan, dimana besarnya peluang pedagang Madura yang memiliki pengetahuan zakat perdagangan tinggi untuk rutin membayar zakat perdagangan sebesar $1.683 \mathrm{kali}$ dibandingkan tidak pernah membayar zakat perdagangan.

Nilai koefisien lingkungan kerja (X_LKRJ) sebesar -0.499 dan Exp (B) sebesar 0.607. Nilai koefisien lingkungan kerja bertanda negatif berarti tingginya pengaruh lingkungan kerja pedagang Madura mempunyai peluang yang lebih kecil dibandingkan rendahnya pengaruh lingkungan kerja pedagang Madura untuk bersikap rutin membayar zakat perdagangan dibandingkan tidak pernah membayar zakat perdagangan, dimana peluangnya sebesar 0.607 kali. Berarti rendahnya pengaruh lingkungan kerja pedagang Madura lebih berpeluang untuk tidak pernah membayar zakat perdagangan dibandingkan rutin membayar zakat perdagangan.

Nilai koefisien religiusitas ( $\mathrm{X}_{3}$ RLGT) sebesar 0.011 dan Exp (B) sebesar 1.011 yang berarti, pedagang Madura yang memiliki religiusitas tinggi mempunyai peluang yang lebih besar dibandingkan pedagang Madura yang memiliki religiusitas rendah untuk bersikap rutin membayar zakat perdagangan dibandingkan tidak pernah membayar zakat perdagangan, dimana besarnya peluang pedagang Madura yang memiliki religiusitas tinggi untuk rutin membayar zakat perdagangan sebesar 1.011 kali dibandingkan tidak pernah membayar zakat perdagangan.

Nilai koefisien pendidikan (X__PND) sebesar 0.138 dan Exp (B) sebesar 1.148 yang berarti, pedagang Madura yang menempuh pendidikan lebih lama mempunyai peluang yang lebih besar dibandingkan pedagang Madura yang menempuh pendidikan hanya sebentar untuk bersikap rutin dimana besarnya peluang pedagang Madura yang menempuh pendidikan lebih lama untuk rutin membayar zakat perdagangan sebesar 1.148 kali dibandingkan tidak pernah membayar zakat perdagangan.

\section{Uji Multikolinieritas}

Untuk mengetahui apakah antarvariabel pengetahuan $\left(X_{1}\right)$, lingkungan kerja $\left(X_{2}\right)$, religiusitas $\left(X_{3}\right)$, dan pendidikan $\left(\mathrm{X}_{4}\right)$ terjadi hubungan linier yang kuat maka dilakukan uji multikolinieritas dengan cara menghitung koefisien korelasi antarvariabel bebasnya dan hasilnya ditunjukkan pada Tabel 5 berikut. 
Tabel 5 Uji multikolinieritas

\begin{tabular}{llrrrr}
\hline & & \multicolumn{1}{c}{ X1 } & \multicolumn{1}{c}{ X2 } & \multicolumn{1}{c}{ X3 } & \multicolumn{1}{c}{ X4 } \\
\hline X1 & Pearson Correlation & 1 & $-.428^{* *}$ & $.277^{* *}$ & $.411^{* *}$ \\
X2 & Pearson Correlation & $-.428^{* * *}$ & 1 & -.158 & $-.416^{* * *}$ \\
X3 & Pearson Correlation & $.277^{* *}$ & -.158 & 1 & $.276^{* *}$ \\
X4 & Pearson Correlation & $.411^{* *}$ & $-.416^{* *}$ & $.276^{* * *}$ & 1 \\
\hline
\end{tabular}

Keterangan : **) Correlation is significant at the 0.01 level (2-tailed).

Berdasarkan Tabel 5 dapat dilihat bahwa tidak terdapat multikolinieritas antarvariabel variabel pengetahuan $\left(\mathrm{X}_{1}\right)$, lingkungan kerja $\left(\mathrm{X}_{2}\right)$, religiusitas $\left(\mathrm{X}_{3}\right)$, dan pendidikan $\left(\mathrm{X}_{4}\right)$ dikarenakan koefisien korelasi antarvariabel pada variabel pengetahuan $\left(\mathrm{X}_{1}\right)$, lingkungan kerja $\left(\mathrm{X}_{2}\right)$, religiusitas $\left(\mathrm{X}_{3}\right)$, dan pendidikan $\left(\mathrm{X}_{4}\right)$ antara $-0.428-0.411$, tidak ada nilainya secara absolut yang lebih besar dari 0.8 $\left(\mathrm{r}_{\text {hitung }}<0.8\right)$.

\section{Kelayakan Model}

Untuk mengetahui apakah model yang digunakan mampu menjelaskan data dengan baik, dilakukan uji kelayakan model dan diperoleh hasil sebagai berikut.

\begin{tabular}{lrrr}
\multicolumn{4}{c}{ Tabel 6 Goodness-of-fit } \\
\hline & Chi-Square & Df & \multicolumn{1}{c}{ Sig. } \\
\hline Pearson & 190.539 & 188 & .435 \\
Deviance & 137.197 & 188 & .998 \\
\hline
\end{tabular}

Berdasarkan Tabel 6 dapat dilihat bahwa nilai Pearson $\chi 2$ lebih besar dari nilai probabilitas $(0.435>0.05)$ dan Deviance $\chi 2$ juga lebih besar dari nilai probabilitas $(0.998>0.05)$. Hal tersebut menujukkan bahwa secara statistik model sesuai atau cocok dengan data empiris dan juga menunjukkan bahwa model mampu menjelaskan data dengan baik.

\section{Koefisien Determinasi Model}

Besarnya koefisien determinasi dari model sikap pembayaran zakat perdagangan ditunjukkan pada Tabel 7 berikut.

\begin{tabular}{lr}
\multicolumn{2}{c}{ Tabel 7 Pseudo $R$-square } \\
\hline Cox and Snell & .464 \\
Nagelkerke & .534 \\
McFadden & .308 \\
\hline
\end{tabular}

Berdasarkan Tabel 7 nilai Nagelkerke $\mathrm{R}^{2}$ sebesar 0.534 (53.4\%), artinya sebesar $53.4 \%$ variasi variabel sikap pedagang Madura dalam membayar zakat perdagangan (Y) dapat dijelaskan variabel pengetahuan $\left(\mathrm{X}_{1}\right)$, lingkungan kerja $\left(\mathrm{X}_{2}\right)$, religiusitas $\left(\mathrm{X}_{3}\right)$, dan pendidikan $\left(\mathrm{X}_{4}\right)$. Sisanya sebesar $46.6 \%$ dijelaskan oleh variabel lain yang tidak masuk dalam model. 
Kemudian keakuratan dari model yang digunakan untuk memprediksi secara tepat data yang sebenarnya ditunjukkan oleh hasil pada Tabel 8 berikut.

Tabel 8 Classification

\begin{tabular}{lcccc}
\hline & \multicolumn{4}{c}{ Predicted } \\
\cline { 2 - 5 } & $\begin{array}{c}\text { Tidak pernah } \\
\text { membayar zakat } \\
\text { perdagangan }\end{array}$ & $\begin{array}{c}\text { Kadang-kadang } \\
\text { membayar zakat } \\
\text { perdagangan }\end{array}$ & $\begin{array}{c}\text { Rutin membayar } \\
\text { zakat } \\
\text { perdagangan }\end{array}$ & $\begin{array}{c}\text { Percent } \\
\text { Correct }\end{array}$ \\
\hline $\begin{array}{l}\text { Observed } \\
\text { zakat pernah membayar }\end{array}$ & 35 & 0 & 6 & $85.4 \%$ \\
$\begin{array}{l}\text { Kadang-kadang membayar } \\
\text { zakat perdagangan }\end{array}$ & 7 & 0 & 8 & $0.0 \%$ \\
$\begin{array}{l}\text { Rutin membayar zakat } \\
\text { perdagangan }\end{array}$ & 9 & 0 & 35 & $79.5 \%$ \\
\hline Overall Percentage & $51.0 \%$ & $0.0 \%$ & $49.0 \%$ & $70.0 \%$ \\
\hline
\end{tabular}

Berdasarkan Tabel 8, dapat dilihat bahwa dari 41 pedagang yang tidak pernah membayar zakat perdagangan yang diprediksi model tidak pernah membayar zakat perdagangan adalah 35 pedagang, berarti tingkat ketepatan prediksinya $85.4 \%$. Dari 15 pedagang yang kadang-kadang membayar zakat perdagangan yang diprediksi model kadang-kadang membayar zakat perdagangan tidak ada, berarti tingkat ketepatan prediksinya $0 \%$. Dari 44 pedagang yang rutin membayar zakat perdagangan yang diprediksi model rutin membayar zakat perdagangan adalah 35 pedagang, berarti tingkat ketepatan prediksinya $79.5 \%$. Secara keseluruhan dari 100 pedagang yang diprediksi sikapnya terhadap kewajiban membayar zakat perdagangan oleh model secara tepat sebanyak $70.0 \%$.

\section{Uji Hipotesis}

\section{Uji simultan}

Untuk mengetahui apakah variabel pengetahuan $\left(X_{1}\right)$, lingkungan kerja $\left(X_{2}\right)$, religiusitas $\left(X_{3}\right)$, dan pendidikan $\left(\mathrm{X}_{4}\right)$ secara simultan berpengaruh signifikan terhadap sikap pembayar zakat perdagangan digunakan Likelihood Ratio Tests dan hasilnya ditunjukkan pada Tabel 9 berikut.

Tabel 9 Model fitting information

\begin{tabular}{lcccr}
\hline & \multicolumn{3}{c}{ Model Fitting Criteria } & \multicolumn{3}{c}{ Likelihood Ratio Tests } & \\
\cline { 2 - 5 } Model & -2 Log Likelihood & Chi-Square & df & Sig. \\
\hline Intercept Only & 200.885 & & & \\
Final & 138.583 & 62.302 & 8 & .000 \\
\hline
\end{tabular}

Berdasarkan Tabel 9 dapat dilihat bahwa nilai Chi-Square hitung $\left(\mathrm{X}_{\text {hitung }}^{2}\right)$ sebesar 62.244 dengan derajat bebas sebesar 8 dan tingkat signifikansi 5\% diperoleh nilai Chi-Square tabel $\left(\mathrm{X}_{\text {tabel }}^{2}\right)$ sebesar 15.5073, dimana nilai Chi-Square hitung> Chi-Square tabel (62.302>15.5073). Selain itu, dapat juga dilihat bahwa nilai signifikansi sebesar $0.000<$ nilai $\alpha(0.05)$. Jadi, dari penjelasan di atas dapat disimpulkan bahwa secara simultan variabel pengetahuan $\left(\mathrm{X}_{1}\right)$, lingkungan kerja $\left(\mathrm{X}_{2}\right)$, religiusitas $\left(\mathrm{X}_{3}\right)$, dan pendidikan $\left(\mathrm{X}_{4}\right)$ memengaruhi sikap pedagang Madura dalam membayar zakat perdagangan.

\section{Uji parsial}

Untuk mengetahui apakah variabel pengetahuan $\left(X_{1}\right)$, lingkungan kerja $\left(X_{2}\right)$, religiusitas $\left(X_{3}\right)$, dan pendidikan $\left(\mathrm{X}_{4}\right)$ secara parsial berpengaruh signifikan terhadap sikap pembayar zakat perdagangan digunakan Likelihood Ratio Tests dan hasilnya ditunjukkan pada Tabel 10 berikut. 
Tabel 10 Likelihood ratio tests

\begin{tabular}{lrrrr}
\hline & \multicolumn{3}{c}{ Model Fitting Criteria } & \multicolumn{2}{c}{ Likelihood Ratio Tests } \\
\cline { 2 - 6 } Effect & -2 Log Likelihood of Reduced Model & Chi-Square & df & \multicolumn{1}{c}{ Sig. } \\
\hline Intercept & 149.505 & 10.922 & 2 & .004 \\
X1_PZPDG & 164.082 & 25.499 & 2 & $.000^{*}$ \\
X2_LKRJ & 147.040 & 8.456 & 2 & $.015^{*}$ \\
X3_RLGT & 138.932 & .349 & 2 & .840 \\
X4_PND & 141.584 & 3.000 & 2 & .223 \\
\hline
\end{tabular}

Keterangan : *) df = 2 sebesar 5.99147 pada signifikansi $5 \%$

Pengetahuan zakat perdagangan $\left(\mathrm{X}_{1}\right)$ signifikan memengaruhi sikap pedagang Madura dalam membayar zakat perdagangan dengan tingkat kepercayaan 95\%. Hal tersebut disebabkan nilai ChiSquare hitung > Chi-Square tabel $(25.512>5.99147)$ atau nilai koefesien signifikansi $<$ nilai $\alpha$ $(0.000<0.05)$.

Lingkungan kerja $\left(\mathrm{X}_{2}\right)$ signifikan memengaruhi sikap pedagang Madura dalam membayar zakat perdagangan dengan tingkat kepercayaan 95\%. Hal tersebut disebabkan nilai Chi-Square hitung > Chi-Square tabel $(8.377>5.99147)$ atau nilai koefesien signifikansi $<$ nilai $\alpha(0.015<0.05)$.

Religiusitas $\left(\mathrm{X}_{3}\right)$ tidak signifikan memengaruhi sikap pedagang Madura dalam membayar zakat perdagangan pada tingkat kepercayaan 95\%. Hal tersebut disebabkan nilai Chi-Square hitung < ChiSquare tabel $(0.320<5.99147)$ atau nilai koefesien signifikansi $<$ nilai $\alpha(0.852>0.05)$.

Pendidikan $\left(\mathrm{X}_{4}\right)$ tidak signifikan memengaruhi sikap pedagang Madura dalam membayar zakat perdagangan. pada tingkat kepercayaan 95\%. Hal tersebut disebabkan nilai Chi-Square hitung < ChiSquare tabel $(2.836<5.99147)$ atau nilai koefesien signifikansi $<$ nilai $\alpha(0.242>0.05)$.

\section{Pengaruh Pengetahuan Zakat Perdagangan terhadap Sikap Pedagang Madura dalam Membayar Zakat Perdagangan}

Pengetahuan zakat perdagangan berpengaruh positif dan signifikan terhadap sikap pedagang Madura dalam melaksanakan kewajiban membayar zakat perdagangan. Semakin tinggi pengetahuan tentang zakat perdagangan yang dimiliki pedagang Madura, maka kecenderungan pedagang Madura untuk membayar zakat perdagangan juga semakin besar. Kecenderungan secara rutin membayar zakat perdagangan lebih besar dibandingkan kadang-kadang membayar zakat perdagangan .

Mayoritas pedagang Madura memiliki tingkat pengetahuan zakat perdagangan tinggi. Sehingga dengan memiliki pengetahuan zakat perdagangan yang baik tentunya responden memiliki kesadaran untuk menaati kewajiban yang harus dilaksanakan sesuai dengan perintah Allah SWT. Pengetahuan tentang zakat ini mengenai kewajiban, tujuan, syarat, manfaat perhitungan, dan sanksi yang akan diperoleh jika tidak membayar zakat. Hal tersebut sangat penting untuk meningkatkan kepatuhan dalam membayar zakat.

Dengan pengetahuan yang dimiliki ini juga akan menimbulkan keyakinan dan kepercayaan bahwa dengan melaksanakan kewajiban membayar zakat perdagangan akan memberikan manfaat dalam hidupnya, yaitu keberkahan dalam harta yang dimiliki. Hasill ini penelitian sejalan dengan riset yang dilakukan oleh Sukri et al. (2016) mendapati bahwa pengetahuan zakat berpengaruh signifikan terhadap kepatuhan membayar zakat emas pada staf UUM. Kemudian dilanjutkan dengan penelitian Othman et al. (2017) mendapati bahwa pengetahuan memiliki hubungan positif dan signifikan terhadap niat membayar zakat penghasilan. Selanjutnya penelitian Zakariah et al. (2018) mendapati bahwa pengetahuan Islam berpengaruh terhadap motivasi muzaki dalam membayar zakat. 


\section{Pengaruh Lingkungan Kerja terhadap Sikap Pedagang Madura dalam Membayar Zakat Perdagangan}

Lingkungan kerja berpengaruh terhadap sikap pedagang Madura di Kota Malang dalam melaksanakan kewajiban membayar zakat perdagangan. Semakin besar pengaruh lingkungan kerja responden, maka kecenderungan responden untuk membayar zakat perdagangan semakin besar. Begitu juga sebaliknya, semakin kecil pengaruh lingkungan kerja responden, maka kecenderungan responden untuk membayar zakat perdagangan semakin kecil.

Berdasarkan hasil penelitian didapati bahwa sebagian besar responden menyatakan bahwa lingkungan kerja responden memiliki pengaruh yang rendah terhadap sikap responden dalam membayar zakat perdagangan. Adanya pengaruh ini kemungkinan disebabkan karena dalam melakukan suatu tindakan responden khususnya dalam membayar zakat perdagangan tentunya mengacu pada suatu kelompok atau individu yang dijadikan acuan dalam bersikap.

Sebelum melakukan perbuatan yang mengacu pada suatu kelompok atau individu yang dijadikan acuan dalam bersikap tentu responden telah melakukan penilaian atas tindakan yang dilihat dan diperoleh dari pengalaman sebelumnya. Maka apabila perilaku tersebut dianggap baik, responden akan menirukan dengan tujuan agar mereka dapat diterima di kalangan kelompok tertentu yang dijadikan acuan. Selain itu, mereka yakin bahwa dengan melakukan perbuatan yang sesuai dengan perilaku lingkungan kerja yang berpedoman pada syariat Islam tentunya juga akan memberikan dampak yang positif bagi kehidupan mereka.

Sejalan dengan penjelasan Azwar (2013) dalam interaksi sosial, terjadi hubungan saling memengaruhi antara individu yang satu dengan yang lain, terjadi hubungan timbal balik yang turut memengaruhi pola perilaku masing-masing individu sebagai anggota masyarakat. Dalam interaksi sosial, individu bereaksi membentuk pola sikap tertetu terhadap berbagai obyek psikologis yang dihadapinya. Faktorfaktor yang memengaruhi pembentukan sikap, yaitu pengalaman pribadi, kebudayaan, orang lain yang dianggap penting, media massa, institusi atau lembaga pendidikan dan lembaga agama, serta faktor emosi dalam diri individu.

Hasil penelitian ini juga sejalan dengan penelitian Bakar dan Rashid (2010) mendapati bahwa akademisi yang membayar zakat dipengaruhi oleh faktor sosial. Dilanjutkan dengan penelitian Ahmad et al. (2011) mendapati bahwa kelompok acuan (teman, relasi, dan kolega) berpengaruh positif dan signifikan terhadap kepatuhan membayar zakat. Dilanjutkan penelitian Heikal et al. (2014) mendapati bahwa norma subjektif berpengaruh positif dan signifikan terhadap niat muzaki untuk membayar zakat perdagangan diantara pedagang di Kota Lhokseumawe.

Dilanjutkan dengan penelitian Azman dan Bidin (2015) mendapati bahwa variabel kelompok acuan berpengaruh positif dan signifikan terhadap perilaku kepatuhan zakat tabungan. Kemudian dilanjutkan Bin-Nashwan et al. (2017) mendapati bahwa norma subyektif berpengaruh signifikan terhadap niat kepatuhan zakat bisnis. Sedangkan penelitian ini tidak sejalan dengan penelitian Ridlwan dan Sukmana (2017) mendapati faktor sosial tidak berpengaruh terhadap motivasi membayar zakat di BAZ wilayah Jawa Timur.

\section{Pengaruh Religiusitas terhadap Sikap Pedagang Madura dalam Membayar Zakat Perdagangan}

Religiusitas tidak memengaruhi sikap pedagang Madura terhadap kewajiban membayar zakat perdagangan. Semestinya semakin tinggi religiusitas responden, maka kecenderungan responden untuk membayar zakat perdagangan semakin tinggi. Begitu juga sebaliknya, semakin rendah religiusitas responden, maka kecenderungan responden untuk membayar zakat perdagangan semakin kecil.

Berdasarkan hasil penelitian, mayoritas responden memiliki tingkat religiusitas yang tinggi, yaitu dengan menerapkan perintah agama Islam dalam kegiatan sehari-harinya. Namun, religiusitas tidak 
berpengaruh pada sikap terhadap kewajiban membayar zakat perdagangan kemungkinan disebabkan karena kurangnya kesadaran yang dimiliki oleh responden, dimana kesadaran ini berhubungan dengan keyakinan yang didapat dari pengetahuan. Tingkat kesadaran inilah yang menjadi faktor utama seseorang dalam melaksanakan kewajiban agama, ketika seseorang memiliki tingkat kesadaran yang tinggi dalam melaksanakan kegiatan keagamaannya, maka seseorang tersebut tidak akan melakukan pelanggaran.

Selain itu, juga kemungkinan disebabkan oleh belum tercapainya syarat-syarat pembayaran zakat perdagangan seperti nisab, haul, serta harta kekayaan yang terbebas dari utang. Hasil penelitian sejalan dengan penelitian Ahmad et al. (2011) mendapati bahwa keimanan tidak berpengaruh signifikan terhadap kepatuhan zakat. Kemudian dilanjutkan dengan penelitian Sukri et al. (2016) mendapati nilai religiusitas tidak berpengaruh terhadap kepatuhan membayar zakat emas. Selanjutnya Mukhlis dan Beik (2013) mendapati bahwa faktor-faktor yang memengaruhi tingkat kepatuhan membayar zakat di Kabupaten Bogor adalah faktor keagamaan seperti iman, pemahaman agama, dan balasan.

Hasil penelitian ini juga tidak sejalan dengan penelitian Bakar dan Rashid (2010) mendapati bahwa keimanan berpengaruh sangat signifikan terhadap kesadaran membayar zakat pendapatan. Kemudian dilanjutkan dengan penelitian Idris et al. (2012) menemukan adanya hubungan positif dan signifikan antara religiusitas dan perilaku kepatuhan zakat bahkan religiusitas memiliki peranan penting dalam perilaku kepatuhan zakat.

Dilanjutkan dengan penelitian Rosyadi (2013) mendapati bahwa komitmen pada ajaran Islam berpengaruh positif terhadap kepatuhan menunaikan zakat maal. Kemudian dilanjutkan dengan penelitian Azman dan Bidin (2015) mendapati bahwa variabel religiusitas berpengaruh terhadap perilaku kepatuhan zakat tabungan. Sobana et al. (2016) mengemukakan bahwa komitmen pada aturan Islam berpengaruh terhadap kepatuhan zakat maal.

Dilanjutkan dengan Perbawa dan Abdullah (2016) yang menyatakan bahwa religiusitas berpengaruh signifikan terhadap kesadaran membayar zakat di BAZNAS Indonesia. Kemudian dilanjutkan dengan Othman et al. (2017) yang mendapati religiusitas berpengaruh positif dan signifikan terhadap niat membayar zakat pendapatan. Ridlwan dan Sukmana (2017) mendapati bahwa religiusitas berpengaruh signifikan terhadap motivasi membayar zakat di agensi regional amil zakat Jawa Timur.

\section{Pengaruh Pendidikan terhadap Sikap Pedagang Madura dalam Membayar Zakat Perdagangan}

Pendidikan tidak memengaruhi sikap pedagang Madura di Kota Malang terhadap kewajiban membayar zakat perdagangan. Semestinya semakin lama atau jenjang pendidikan yang semakin tinggi pendidikan yang ditempuh responden, kecenderungan responden untuk membayar zakat perdagangan semakin besar. Begitu juga sebaliknya, semakin sedikit atau jenjang pendidikan yang semakin rendah pendidikan yang ditempuh responden, kecenderungan responden untuk membayar zakat perdagangan semakin kecil.

Dengan menempuh pendidikan, baik formal maupun non formal dapat memberikan pengetahuan yang lebih mendalam mengenai zakat perdagangan. Kebanyakan pedagang tidak hanya menempuh pendidikan secara formal tetapi juga non formal. Pendidikan formal yang ditempuh oleh responden mayoritas adalah tingkat SD. Bagi mereka pendidikan formal tidak terlalu penting. Bagi mereka pendidikan non formal lebih mereka pentingkan karena mereka berprinsip bahwa percuma seseorang berpendidikan tinggi, namun pengetahuan mereka pada agama kurang. Maka tidak salah jika kebanyakan dari mereka memilih pendidikan yang lebih mengutamakan pada pendidikan agama, seperti pondok pesantren dan tempat selain pesantren namun lebih mengutamakan pendidikan agama (misalnya masjid tempat mereka mengaji). 
Hasil penelitian sejalan dengan penelitian Merlinda (2015), bahwa pendidikan formal dan pendidikan informal tidak berpengaruh terhadap keputusan muslim dalam membayar zakat. Dilanjutkan dengan hasil kajian Ahmad et al. (2011) menemukan bahwa pendidikan berpengaruh positif terhadap kepatuhan zakat. Selanjutnya Sobana et al. (2016) mendapati tingkat pendidikan berpengaruh terhadap kepatuhan zakat maal.

\section{SIMPULAN}

Secara simultan variabel pengetahuan $\left(\mathrm{X}_{1}\right)$, lingkungan kerja $\left(\mathrm{X}_{2}\right)$, religiusitas $\left(\mathrm{X}_{3}\right)$, dan pendidikan $\left(\mathrm{X}_{4}\right)$ signifikan memengaruhi sikap pedagang Madura dalam membayar zakat perdagangan. Kemudian secara parsial variabel pengetahuan $\left(\mathrm{X}_{1}\right)$ dan lingkungan kerja $\left(\mathrm{X}_{2}\right)$ memengaruhi sikap pedagang Madura dalam membayar zakat perdagangan. Sedangkan secara parsial, variabel religiusitas $\left(\mathrm{X}_{3}\right)$, dan pendidikan $\left(\mathrm{X}_{4}\right)$ tidak memengaruhi sikap pedagang Madura dalam membayar zakat perdagangan. Diasarankan kepada para pedagang Madura untuk memiliki tingkat kesadaran yang lebih baik lagi dalam melaksanakan kewajiban membayar zakat perdagangan. Dengan tingginya kesadaran membayar zakat perdagangan nantinya akan berdampak pada tingginya jumlah pengumpulan zakat dan bantuan yang disalurkan pun semakin banyak. Dengan peningkatan pembayaran zakat perdagangan diharapkan juga dapat mengurangi tingkat kemiskinan sehingga meningkatkan pertumbuhan ekonomi khususnya di Kota Malang.

\section{DAFTAR PUSTAKA}

Ahmad, S., Nor, N.G.Md., \& Daud, Z. (2011) Tax-based modelling of zakat compliance. Jurnal Ekonomi Malaysia, 45, 101-108.

Azman, F. M.N. \& Bidin, Z. (2015) Factors influencing zakat compliance behavior on saving. International Journal of Business and Social Research, 5(1), 118-128.

Azwar, S. (2013) Sikap Manusia Teori dan Pengukurannya. Yogyakarta, Pustaka Pelajar.

Bakar, N.B.A. \& Rashid, H.M.A. (2010) Motivations of paying zakat on income: Evidence from Malaysia. International Journal of Economics and Finance, 2(3), 76-84.

Bin-Nashwan, S.A., Abdul, H.J., \& Ramli, Abd.R. (2017) Perception of business owner toward business zakah compliance intention. World Journal of Islamic History and Civilization, 7(2), $17-$ 22.

[BPS Malang Kota] Badan Pusat Statisik Kota Malang. (2017) Distribusi Persentase Produk Domestik Regional Bruto Kota Malang Atas Dasar Harga Berlaku Menurut Lapangan Usaha, 2010-2016. Malang, BPS Malang Kota.

Daud, Z., Ahmad, S., \& Rahman, A.F. (2011) model perilaku kepatuhan zakat: suatu pendekatan teori. Iqtishoduna: Jurnal Ekonomi dan Bisnis Islam, 7(1), 1-21.

Ghozali, I. (2011) Aplikasi Analisis Multivariate Dengan Program IBM SPSS19. Semarang, Universitas Diponegoro.

Hasbi, A.F. (2008) 125 Masalah Zakat. Solo, Tiga Serangkai.

Heikal, M., Khaddafi, M., \& Falahuddin. (2014) The intention to pay zakat commercial: An application of revised theory of planned behavior. Journal of Economics and Behavioral Studies, 6(9), 727-734.

Idris, K.Md., Bidin, Z., \& Saad, R.A.J. (2012) Islamic religiosity measurement and its relationship with business income zakat compliance behavior. Jurnal Pengurusan Malaysia, 34, 3-10.

Merlinda, S. (2015) Determinan Keputusan Muslim dalam Pembayaran Zakat Perdagangan (Studi Kasus di Kota Malang Provinsi Jawa Timur) [tesis]. Malang, Universitas Brawijaya.

Mukhlis, A. \& Beik, I.S. (2013) Analisis faktor-faktor yang memengaruhi tingkat kepatuhan membayar zakat: Studi kasus Kabupaten Bogor. Al-Muzara'ah, 1(1), 83-106.

Nachrowi, N.D. (2008) Penggunaan Teknik Ekonometrika. Jakarta, PT Raja Grafindo Persada.

Othman, Y.H., Yusuff, M.S.S., Saufi, M.S.A.Z., \& Hafsha, S. (2017) The influence of knowledge, Islamic religiosity and self-efficacy on the intention to pay income zakat among public educators 
in Kedah, Malaysia. International Journal of Academic Research in Business and Social Sciences, 7(11), 1117-1127.

Perbawa, A. \& Abdullah, R. (2016) Determinant factors of awareness for paying zakat on BAZNAS, Indonesia. SSRN.

Ridlwan, A.A. \& Sukmana, R. (2017) The determinant factors of motivation to pay zakat in regional amil zakat agency of East Java. Karsa: Journal of Social and Islamic Culture, 25(2), 334-345.

Rosyadi, I. (2013) Model prediksi kepatuhan menunaikan zakat maal. Proceeding Seminar Nasional Dan Call For Papers Sancall, 37-50.

Sugiyono. (2014) Metode Penelitian kuantitatif, Kualitatif, dan R\& D. Bandung, Alfabeta.

Sobana, D.H., Husaeni, U.A., Jamil, I., \& Saepudin, D. (2016) The variables that affect compliance of muslim merchants for zakat maal in the District of Cianjur. International Journal of Zakat, $1(1), 78-87$.

Sukri, N.F.A.M., Wahab, N.A., \& Hamed A.B. (2016) Compliance to pay zakat on gold: A study on UUM staff. Global Review of Islamic Economics and Business, 4(2), 90-101.

Zakariah, M.A., Zakariah, M., Suciana, I., Setiawan R., Reza, Sultan, \& Nasution A.H. (2018) Regression analysis of motivation factors for paying a zakat to strengtheness of ummah in Kolaka Regency. Jurnal Ekonomi Bisnis Syariah, 1(1), 1-8. 